\title{
Late and very late stent thrombosis following drug-eluting stent implantation in unprotected left main coronary artery: a multicentre registry
}

\author{
Alaide Chieffo ${ }^{1}$, Seung-Jung Park2 ${ }^{2}$ Emanuele Meliga ${ }^{3}$, Imad Sheiban ${ }^{4}$, Michael S. Lee ${ }^{5}$, \\ Azeem Latib', Young-Hak Kim², Marco Valgimigli ${ }^{3}$, Dario Sillano4, Valeria Magni ${ }^{1}$, \\ Giuseppe Biondi-Zoccai ${ }^{4}$, Matteo Montorfano', Flavio Airoldi ${ }^{1,6}$, Renata Rogacka ${ }^{1}$, \\ Mauro Carlino1, lassen Michev ${ }^{1,6}$, Cheol-Whan Lee², Myeong-Ki Hong², \\ Seong-Wook Park ${ }^{2}$, Claudio Moretti ${ }^{4}$, Erminio Bonizzoni ${ }^{7}$, Giuseppe M. Sangiorgi ${ }^{1,6}$, \\ Jonathan Tobis ${ }^{5}$, Patrick W. Serruys ${ }^{3}$, and Antonio Colombo ${ }^{1,6 *}$
}

${ }^{1}$ San Raffaele Scientific Institute, Via Olgettina 60, 20132 Milan, Italy; ${ }^{2}$ Asan Medical Center, University of Ulsan College of Medicine, Seoul, Republic of Korea; ${ }^{3}$ Erasmus Medical Center, Thoraxcenter, Rotterdam, The Netherlands; ${ }^{4}$ San Giovanni Battista Hospital, Turin, Italy; ${ }^{5}$ University of California, Los Angeles Medical Center, CA, USA; ${ }^{6}$ EMO Centro Cuore Columbus, Milan, Italy; and ${ }^{7}$ Institute of Medical Statistics and Biometry, University of Milan, Milan, Italy

Received 31 January 2008; revised 17 April 2008; accepted 29 May 2008; online publish-ahead-of-print 18 June 2008

See page 2064 for the editorial comment on this article (doi:10.1093/eurheartj/ehn342)

Aims

Methods and results

\section{Conclusion}

Keywords
To evaluate the occurrence of late and very late stent thrombosis (ST) following elective drug-eluting stent (DES) implantation in unprotected left main coronary artery (LMCA) stenosis in a large multicentre registry.

All 731 consecutive patients who had sirolimus- or paclitaxel-eluting stent electively implanted in de novo lesions on unprotected LMCA in five centres were included. ST was defined according to Academic Research Consortium definitions. Four (0.5\%) patients had a definite ST: three early (two acute and one subacute) and one late ST, no cases of very late definite ST were recorded. All patients survived from the event. Three patients had a probable ST. Therefore, $7 / 731(0.95 \%)$ patients had a definite or a probable ST and all were on dual antiplatelet therapy at the time of the event. Possible (eight late and 12 very late) ST occurred in 20 (2.7\%) patients. At $29.5 \pm 13.7$ months follow-up, a total of $45(6.2 \%)$ patients had died; 31 (4.2\%) of cardiac death. Ninety five (12.9\%) patients had a target-vessel and 76 (10.4\%) a target-lesion revascularization. Angiographic follow-up was performed in 548 patients (75\%): restenosis occurred in 77 (14.1\%) patients.

Elective treatment of LMCA stenosis with DES appears safe with a $0.9 \%$ incidence of definite and probable ST at $29.5 \pm 13.7$ months.

Stent • Left main coronary artery • Drug-eluting stents • Stent thrombosis

\section{Introduction}

Some concerns have recently been raised regarding the risk of late and very late stent thrombosis (ST) following drug-eluting stent (DES) implantation. ${ }^{1-10}$ Registry data of percutaneous coronary interventions $(\mathrm{PCl})$ with DES use in unprotected left main coronary artery (LMCA) lesions showed that, at mid-term clinical follow-up, this is a feasible and safe approach. ${ }^{11-19}$ To date, no study has specifically addressed the prevalence and predictors of late and very late ST following elective DES implantation in unprotected LMCA lesions. The aim of the present study is therefore to evaluate the occurrence of late and very late ST following elective DES implantation in unprotected LMCA stenosis in a large multicentre registry.

* Corresponding author: Tel: +3902 2643 7331, Fax: +3902 2643 7339, Email: colombo.antonio@hsr.it

Published on behalf of the European Society of Cardiology. All rights reserved. (C) The Author 2008. For permissions please email: journals.permissions@oxfordjournals.org. 


\section{Methods}

This study included all consecutive patients with a stenosis in an unprotected LMCA electively treated with PCl and sirolimus- (SES, Cypher, Cordis, Johnson \& Johnson Company, Warren, NJ, USA) or paclitaxel-eluting stent (PES, Taxus, Boston Scientific, Natick, MA, USA) implantation in five centres (San Raffaele Hospital and EMO Centro Cuore Columbus in Milan; San Giovanni Battista Hospital in Turin, Italy; Erasmus Medical Center - Thoraxcenter, The Netherlands; the Asan Medical Center, Korea and University of California, Los Angeles Medical Center) between March 2002 and March 2006. The data were prospectively collected in the single centres and retrospectively entered into a common database. Patients with ST or non-ST elevation myocardial infarctions (Mls) were excluded from the analysis. The decision to perform $\mathrm{PCl}$ instead of surgery was considered when one of these two conditions was present: suitable anatomy for stenting and preference by patient for a percutaneous approach or suitable anatomy for stenting and disincentive for surgery defined as a Euroscore $\geq 6$ and/or prior coronary artery bypass grafting (CABG) with failure of all conduits.

Coronary angioplasty and DES implantation were performed according to the practice of fully covering the diseased segment. ${ }^{20,21}$ At the start of the procedure, a bolus of unfractionated heparin was administered at $100 \mathrm{IU} / \mathrm{kg}$ to achieve an activated clotting time of $>250$ s. Glycoprotein Ilb/llla inhibitors were administered at the discretion of the operator. Clinical follow-up was scheduled and obtained for all patients at 1, 6, 12, and 24 months by office visit or direct telephone call to the patients. Patients eligible for longer clinical follow-up were contacted at 36, 48, and 60 months.

Dual antiplatelet therapy (DAT) (i.e. aspirin $100 \mathrm{mg}$ daily and clopidogrel $75 \mathrm{mg}$ daily or ticlopidine $250 \mathrm{mg}$ twice daily) was administrated according to local practice (for at least 6 months after the procedure in Rotterdam and Turin and 12 months in Milan, Seoul, and Los Angeles). All patients were advised to remain on aspirin (100 mg die) lifelong. In addition, cilostazol was also given to some patients for 1 month (in Seoul).

Detailed information on adherence as well as reasons and date for discontinuation of DAT was obtained in all patients.

Angiographic follow-up was scheduled between 4 and 9 months or earlier if non-invasive evaluation or clinical presentation suggested the presence of ischaemia.

\section{Definitions}

ST was defined on the basis of the Academic Research Consortium definitions according to the timing of presentation as early $(0-30$ days), late (31-360 days), or very late (>360 days) and to the following trilevel of certainty:

Definite ST in the presence of an acute coronary syndrome and either angiographic or pathological (autopsy) confirmation of ST;

Probable ST in case of an acute $\mathrm{MI}$ involving the target-vessel territory without angiographic confirmation of thrombosis or other identified culprit lesion and/or any unexplained death within 30 days;

Possible ST in the case of any unexplained death after 30 days.

The following major adverse cardiac events (MACE), during hospital stay and at follow-up, were also analysed: death, CABG, MI, target lesion revascularization (TLR), and target vessel revascularization (TVR).

Deaths were classified as either cardiac or non-cardiac. Cardiac death was defined as any death due to a cardiac cause (e.g. MI, lowoutput failure, fatal arrhythmia), procedure-related deaths, and death of unknown cause.
Non-Q-wave Ml was defined as an elevation of serum creatine kinase (CK) MB isoenzyme that was three times the upper limit of normal (ULN) in the absence of pathological Q-waves.

Restenosis was defined as $>50 \%$ luminal narrowing at the segment site (stent and $5 \mathrm{~mm}$ proximal and distal) demonstrated at the follow-up angiography, regardless of clinical symptoms.

TLR was defined as any revascularization performed on the treated segment; TVR was defined as any re-intervention performed on the treated vessel considering also treatment of any segment in the left anterior descending and circumflex arteries.

The European system for cardiac operative risk evaluation (Euroscore) was used to stratify the risk of death at 30 days. ${ }^{22}$ The patients were stratified as high risk in the presence of a Euroscore $\geq 6$.

Unstable angina was defined according to the presence of: (i) rest angina (usually $>20 \mathrm{~min}$ ); (ii) new onset ( $<2$ months) severe exertion angina of at least Canadian Cardiovascular Society Classification (CCSC) class III in severity; (iii) recent ( $<2$ months) acceleration of angina as reflected by an increase of at least one CCSC class to at least CCSC class III.

\section{Event adjudication}

All the events in patients included in this registry were first evaluated by at least two co-authors from the participating centres and then by two co-authors of the coordinating centre on the basis of detailed reports from each of the participating centres.

\section{Statistical analysis}

Continuous data were reported as mean \pm standard deviation (SD) or median [interquartile range (IQR)] as appropriate. In general, differences in proportions were tested with $\chi^{2}$ test or Fisher's exact test, while differences in continuous variables with Student's t-test or Wilcoxon rank sum test.

At univariate logistic regression analysis the following covariates were assessed: age, gender, diabetes, left ventricular ejection fraction (LVEF), unstable angina, Euroscore, DAT, duration of DAT $(<6$ months, 6-12 months, $>12$ months), distal LMCA, intravascular ultrasound (IVUS) guidance, baseline reference vessel diameter, baseline minimal luminal diameter, stent type, both branch stenting, crush technique, stent length, final kissing balloon inflation, and maximum inflation pressures. Among continuous variable, no pre-specified cut-off was employed. Because of the small number of events observed in a dataset of 731 patients, exact odds ratios (OR) with associated 95\% confidence intervals $(\mathrm{Cl})$ and two-tailed $P$-values were computed using permutation resampling.

In order to obtain parameter estimates adjusted for potential collinearity among covariates, exact conditional analyses were carried out re-running the exact logistic regressions with one covariate at a time as a fixed factor and treating the remaining as nuisance parameters. ${ }^{23}$ The Statistical Analysis System program version 9.1 (SAS Institute, Cary, NC, USA) was used for data analysis.

All authors have read and agreed to the manuscript as written.

\section{Results}

Baseline clinical, lesion, and procedural characteristics are summarized, respectively, in Tables 1 and 2. A total of 731 patients with unprotected LMCA were electively treated in our centres with DES implantation. One hundred and seventy six (24.0\%) patients were diabetic and 333 (45.5\%) had unstable angina. Mean age was $63.1 \pm 11.8$ years and LVEF $54.8 \pm 10.9 \%$. Median and IQR of Euroscore was 3.0 (2.0-6.0); a Euroscore $\geq 6$ was present in 
Table I Clinical characteristics of the study population

\begin{tabular}{|c|c|}
\hline & $n=731$ patients \\
\hline Age (years) & $63.1 \pm 11.8$ \\
\hline Female gender, $n(\%)$ & $189(25.8)$ \\
\hline Hypertension, n (\%) & $427(58.4)$ \\
\hline Hypercholesterolaemia, n (\%) & $368(50.3)$ \\
\hline Smoking, n (\%) & $247(33.8)$ \\
\hline Diabetes mellitus, $n$ (\%) & $176(24.0)$ \\
\hline Unstable angina, $n(\%)$ & $333(45.5)$ \\
\hline LVEF (\%) & $54.8 \pm 10.9$ \\
\hline Chronic renal failure, $n(\%)$ & $40(5.5)$ \\
\hline Euroscore, median (IQR) & $3.0(2.0-6.0)$ \\
\hline Euroscore $\geq 6, n(\%)$ & $262(35.8)$ \\
\hline
\end{tabular}

LVEF, left ventricular ejection fraction (\%).

Continuous data were reported as mean \pm SD or median and interquartile range (IQR) as appropriate.

Table 2 Lesion and procedural characteristics

\begin{tabular}{|c|c|}
\hline & $n=731$ patients \\
\hline Distal, $n(\%)$ & $559(76.5)$ \\
\hline Number of vessels treated & $2.2 \pm 0.8$ \\
\hline Number of lesions treated & $2.3 \pm 1.5$ \\
\hline IABP, $n(\%)$ & $96(13.1)$ \\
\hline GP IIb/llla inhibitors usage, $n$ (\%) & $102(13.9)$ \\
\hline IVUS guidance, $n$ (\%) & $337(46.1)$ \\
\hline DCA or rotablator, $n(\%)$ & $24(3.3)$ \\
\hline Cypher stent implantation, $n(\%)$ & $536(73.3)$ \\
\hline Taxus stent implantation, $n(\%)$ & $196(26.8)$ \\
\hline Both branches stented/distal, $n$ (\%) & $276(49.4)$ \\
\hline Stent length $(\mathrm{mm})$ & $25.0 \pm 15.1$ \\
\hline Maximum balloon diameter $(\mathrm{mm})$ & $3.7 \pm 0.6$ \\
\hline Maximum pressure inflation (atm) & $17.5 \pm 3.7$ \\
\hline
\end{tabular}

IABP, intra-aortic balloon pump implantation; GP Ilb/llla inhibitors usage, use of glycoprotein IIb/llla inhibitors during the procedure; IVUS, intravascular ultrasound; DCA, directional coronary atherectomy.

Data are presented as percentages and mean \pm SD

$36 \%$ of the patients. The number of treated vessels was $2.2 \pm 0.8$ and the number of lesions $2.3 \pm 1.5 ; 27 \%$ of the patients also had right coronary artery disease. An intra-aortic balloon pump was used in 96 (13.1\%) patients. In 337 (46.1\%) patients IVUS guidance was performed. Reference vessel diameter of the LMCA was $3.7 \pm$ $0.6 \mathrm{~mm}$. At least one SES was implanted in 536 (73.3\%) and PES in 196 (26.8\%) patients; in one patient both PES and SES were used. In 559 (76.5\%) patients the stenosis was located at the distal segment of the LMCA. When the distal left main was treated, the stenting strategy adopted was provisional (cross-over) approach in 283 (50.6\%) patients, 'crush' in 120 (21.5\%), 'V' stenting in 80 (14.3\%), 'modified T' in 52 (9.3\%) and 'culotte' in 24
(4.3\%). Final kissing balloon inflation was performed in $64 \%$ of the cases.

The median duration of DAT was 8.8 months (IQR, 6.0-20.7).

\section{Stent thrombosis \\ Definite stent thrombosis}

Four $(0.54 \%)$ patients had a definite ST. Three patients had an early (two acute and one subacute) and only one a late definite ST.

Early definite stent thrombosis

Among the three patients with early definite ST: one had an intraprocedural ST successfully treated with intravenous administration of abciximab, intracoronary administration of recombinant tissue plasminogen activator ( $r$-TPA) and additional stent implantation (the patient was found to be a poor responder to clopidogrel); the second occurred some hours after the $\mathrm{PCl}$ and was successfully treated with emergency CABG; and the last occurred 12 days after the index procedure. All the three patients had the thrombotic event while on DAT and all of them are alive at the time of this report.

Late and very late definite stent thrombosis

Only one patient had a definite late ST at 3.9 months while on DAT. The patient had an acute anterior $\mathrm{MI}$ and angiographically proven ST in the proximal left anterior descending artery successfully treated with repeat $\mathrm{PCl}$. This patient died of lung cancer 10 months after the thrombotic event. No cases of very late definite ST were recorded.

\section{Probable stent thrombosis}

Probable ST occurred in three patients. In all the three, the event occurred early and was adjudicated because of the occurrence of sudden death within 30 days from the procedure, in the absence of an autopsy or control angiography.

Therefore, a total of $7 / 731$ (0.95\%) patients had a definite or probable ST. Characteristics of patients with definite or probable ST are illustrated in Table 3; baseline, lesion, procedural characteristics of patients with definite or probable ST vs. patients without definite or probable ST are illustrated in Table 4.

At univariate exact logistic (unconditional) analysis, age $(\mathrm{OR}=1.07, \mathrm{Cl} 95 \%$ 1.00-1.16; $P=0.03), \operatorname{LVEF}(\mathrm{OR}=0.94$, $\mathrm{Cl} 95 \% \quad 0.90-0.98 ; P=0.007)$ and Euroscore $(O R=1.19$, Cl 95\% 1.07-1.34; $P=0.003$ ) were correlated to definite or probable ST. At conditional univariate analysis, only LVEF (OR $=0.94$, $\mathrm{Cl} 95 \%$ 0.89-0.99; $P=0.03$ ) and Euroscore ( $O R=1.22, \mathrm{Cl} 95 \%$ $1.06-1.41 ; P=0.008)$ were associated with definite or probable ST (Table 5 and Figure 1A).

\section{Possible stent thrombosis}

Possible stent thrombosis was adjudicated in 20 patients in whom the cause of death was unexplained (no autopsy or control angiography was performed).

Late possible ST occurred in eight and very late possible ST in 12 of these patients. Eight of these patients were on DAT at the time of the event and 12 had suspended DAT (10 because of the hospital protocol, one because of gastric symptoms and 
Table 3 Characteristics of the patients with definite and probable stent thrombosis

\begin{tabular}{|c|c|c|c|c|c|c|c|c|c|}
\hline Patient & $\begin{array}{l}\text { Euro } \\
\text { score }\end{array}$ & $\begin{array}{l}\text { Age } \\
\text { (years) }\end{array}$ & $\begin{array}{l}\text { LVEF } \\
\text { (\%) }\end{array}$ & $\begin{array}{l}\text { Unstable } \\
\text { angina }\end{array}$ & $\begin{array}{l}\text { Lesion } \\
\text { location }\end{array}$ & $\begin{array}{l}\text { Stent } \\
\text { type }\end{array}$ & $\begin{array}{l}\text { Stenting } \\
\text { technique }\end{array}$ & $\begin{array}{l}\text { Time of the } \\
\text { event (days) }\end{array}$ & $\begin{array}{l}\text { DAT at the time } \\
\text { of the event }\end{array}$ \\
\hline \multicolumn{10}{|c|}{ Definite ST } \\
\hline 1 & 1 & 55 & 55 & No & Distal & Taxus & Crush & 0 & Yes \\
\hline 2 & 9 & 72 & 30 & Yes & Distal & Cypher & Cross-over & 0 & Yes \\
\hline 3 & 10 & 71 & 45 & Yes & Distal & Taxus & V & 12 & Yes \\
\hline 4 & 11 & 71 & 35 & No & Distal & Taxus & Crush & 116 & Yes \\
\hline \multicolumn{10}{|c|}{ Probable ST } \\
\hline 1 & 12 & 76 & 40 & Yes & Distal & Cypher & Crush & 12 & Yes \\
\hline 2 & 15 & 78 & 39 & Yes & Ostium & Taxus & Cross-over & 1 & Yes \\
\hline 3 & 10 & 85 & 30 & Yes & Distal & Cypher & Cross-over & 3 & Yes \\
\hline
\end{tabular}

Table 4 Baseline, lesion, procedural characteristics of patients with definite or probable stent thrombosis vs. patients without definite or probable stent thrombosis

\begin{tabular}{|c|c|c|}
\hline & $\begin{array}{l}\text { Patients with } \\
\text { definite or } \\
\text { probable stent } \\
\text { thrombosis } \\
(n=7)\end{array}$ & $\begin{array}{l}\text { Patients without } \\
\text { definite or } \\
\text { probable stent } \\
\text { thrombosis } \\
(n=724)\end{array}$ \\
\hline Age (years) & $72.5 \pm 9.2$ & $63.1 \pm 11.8$ \\
\hline LVEF (\%) & $39.1 \pm 8.8$ & $54.9 \pm 10.8$ \\
\hline Male gender & $5(71.5 \%)$ & $537(74.1 \%)$ \\
\hline Unstable angina & $5(71.5 \%)$ & $328(45.3 \%)$ \\
\hline Diabetes & $2(28.5 \%)$ & $174(24.1 \%)$ \\
\hline Euroscore & $9.6 \pm 4.6$ & $4.0 \pm 3.0$ \\
\hline Distal location & $6(85.7 \%)$ & 554 (76.5\%) \\
\hline Both branch stenting ${ }^{a}$ & $4(66.6 \%)$ & $272(49.1 \%)$ \\
\hline Stent length (mm) & $25.8 \pm 14.0$ & $25.0 \pm 15.8$ \\
\hline Reference vessel (mm) & $3.32 \pm 1.0$ & $3.4 \pm 0.5$ \\
\hline IVUS done & $3(42.1 \%)$ & $334(46.8 \%)$ \\
\hline DAT & $7(100 \%)$ & $117(16.1 \%)$ \\
\hline Myocardial infarction ${ }^{\text {b }}$ & $4(57.1 \%)$ & $9(1.24 \%)$ \\
\hline $\begin{array}{l}\text { Target lesion } \\
\text { revascularization }\end{array}$ & $4(57.1 \%)$ & 74 (10.2\%) \\
\hline Cardiac death & $3(42.8 \%)$ & $28(3.86 \%)$ \\
\hline
\end{tabular}

DAT, dual antiplatelet therapy at the time of the thrombotic event [in patients with definite or probable stent thrombosis (ST)] or at the time of last clinical follow-up (in patients without definite or probable ST)

aBoth branch stenting: the percentages are calculated considering only patients with distal lesion location.

b In myocardial infarctions are excluded peri-procedural myocardial infarctions unless occurred following ST.

one because of abdominal surgery). Clinical characteristics were unfavourable in most of these patients: $8 / 20$ (40\%) were $>75$ years old, $13 / 20(65 \%)$ patient had a LVEF $<40 \%$ and a Euroscore $\geq 6$ (Table 6).

\section{In-hospital and long-term major adverse cardiac events}

In-hospital and long-term clinical outcomes are illustrated in Table 7.

During hospitalization, five $(0.68 \%)$ patients died; all of them were $>75$ years and had a Euroscore $>6$. None of these patients had an angiographically or pathologically proven ST. Sudden death occurred in 2/5, and probable ST cannot be excluded. Non-Qwave $\mathrm{Ml}$ occurred in 69 (9.4\%) of the patients.

At $29.5 \pm 13.7$ months, cumulatively 45 (6.2\%) patients died; 31 (4.2\%) of cardiac death. During the follow-up period, 11 patients experienced a $\mathrm{Ml}$ and nine of them were not in the target vessel (two were due to angiographically proven ST in a stent not in the target vessel). Seventy six (10.5\%) patients underwent TLR and 95 (13.0\%) a TVR (83 re-PCls and 12 CABG). Angiographic follow-up was performed in 548 patients (75\%); restenosis occurred in 77 (14.1\%) of these patients. Notably, the range and extent of clinical follow-up did not differ among the different centres.

At univariate exact logistic (unconditional) analysis, age $(\mathrm{OR}=1.06, \mathrm{Cl} 95 \% 1.03-1.09 ; P=0.0001)$, LVEF $(\mathrm{OR}=0.94$, $\mathrm{Cl} 95 \%$ 0.92-0.96; $P<0.0001)$, Euroscore $(\mathrm{OR}=1.21, \mathrm{Cl} 95 \%$ $1.13-1.30 ; P<0.0001)$, unstable angina $(\mathrm{OR}=3.73, \mathrm{Cl} 95 \%$ 1.54-11.6; $P=0.002)$ and IVUS guidance $(O R=0.93$, $\mathrm{Cl} 95 \%$ 0.16-0.93; $P=0.03$ ) were correlated to cardiac death. At conditional analysis, only unstable angina $(\mathrm{OR}=3.25, \mathrm{Cl} 95 \%$ 1.33-9.05; $P=0.007)$, LVEF $(\mathrm{OR}=0.79, \mathrm{Cl} 95 \% \quad 0.87-0.97$; $P=<0.0001)$ and Euroscore $(\mathrm{OR}=1.18, \mathrm{Cl} 95 \%$ 1.04-1.23; $P=0.003$ ) were correlated to cardiac death (Figure 1B).

\section{Discussion}

The main findings of this study are: (i) the incidence of definite ST is relatively low (0.5\%): $75 \%$ of the cases occurred within 30 days and none after 1 year; all the patients were successfully treated and survived from the event; (ii) the cumulative occurrence of definite and probable ST is $0.95 \%$ and at conditional analysis exact logistic analysis was correlated with the Euroscore and LVEF, but not with 
Table 5 Unconditional and conditional analysis of the predictors of definite and probable stent thrombosis

\begin{tabular}{|c|c|c|c|c|c|c|}
\hline & \multicolumn{3}{|c|}{ Unconditional analysis } & \multicolumn{3}{|c|}{ Conditional analysis } \\
\hline & OR & $95 \%$ exact $\mathrm{Cl}$ & $\mathbf{P}$ & OR & $95 \%$ exact $\mathrm{Cl}$ & $P$ \\
\hline DES type & 0.5174 & $0.1950-1.2693$ & 0.1728 & 0.5531 & $0.2081-1.3732$ & 0.2420 \\
\hline Gender & 0.8708 & $0.1409-9.2236$ & 1.0000 & 0.6773 & $0.1044-7.4699$ & 0.9417 \\
\hline Age (years) & 1.0783 & $1.0052-1.1620$ & 0.0343 & 1.0649 & $0.9860-1.1595$ & 0.1154 \\
\hline Diabetes & 1.2503 & $0.1182-7.7574$ & 1.0000 & 0.8982 & $0.0814-5.8378$ & 1.0000 \\
\hline Unstable angina & 3.0184 & $0.4903-31.9183$ & 0.3171 & 2.7247 & $0.4283-29.6316$ & 0.4045 \\
\hline LVEF (\%) & 0.9436 & $0.9027-0.9829$ & 0.0072 & 0.9417 & $0.8894-0.9934$ & 0.0280 \\
\hline Reference vessel (mm) & 1.1958 & $0.5949-2.9384$ & 0.7899 & 1.2420 & $0.5879-3.4065$ & 0.7482 \\
\hline MLD (mm) & 0.9489 & $0.2923-3.0104$ & 0.9327 & 1.2245 & $0.3775-3.9770$ & 0.7357 \\
\hline Maximum pressure (atm) & 1.1592 & $0.9807-1.3545$ & 0.0798 & 1.1639 & $0.9775-1.3656$ & 0.0862 \\
\hline Stent length (mm) & 1.0055 & $0.9552-1.0474$ & 0.7544 & 1.0152 & $0.9573-1.0656$ & 0.5395 \\
\hline Distal location & 1.8425 & $0.2208-85.4474$ & 0.9695 & 0.7260 & $0.0460-55.1541$ & 1.0000 \\
\hline Kissing balloon inflation & 1.9497 & $0-4.9615$ & 1.0000 & 2.2424 & $0-6.0158$ & 1.0000 \\
\hline Type of stenting technique & 1.9465 & $0.3910-9.6902$ & 0.6171 & 1.5316 & $0.2979-7.8749$ & 1.0000 \\
\hline Both branch stenting & 3.1327 & $0.4454-34.8600$ & 0.3339 & 2.2919 & $0.3134-26.3552$ & 0.5863 \\
\hline Euroscore & 1.1996 & $1.0758-1.3422$ & 0.0026 & 1.2193 & $1.0577-1.4124$ & 0.0076 \\
\hline IVUS & 0.8758 & $0.1273-5.2108$ & 1.0000 & 1.4492 & $0.2006-9.1331$ & 0.9194 \\
\hline DAT discontinuation & 0.1464 & $0.0219-0.8813$ & 0.0347 & 0.1524 & $0.0196-0.9889$ & 0.0485 \\
\hline DAT duration, 12 months & 0.6076 & $0.1193-2.2452$ & 0.8555 & 0.4343 & $0.0836-1.6713$ & 0.3823 \\
\hline DAT duration, 6 months & 1.2958 & $0.2753-4.4804$ & 1.0000 & 1.3891 & $0.2899-4.9297$ & 1.0000 \\
\hline
\end{tabular}

the duration of DAT (at the time of the thrombotic event all patients were on DAT); (iii) there was a $4.2 \%$ cumulative cardiac mortality and $6.2 \%$ cumulative total mortality rate at $29.5 \pm 13.7$ months follow-up.

According to current European Society of Cardiology and American Heart Association/American College of Cardiology guidelines the presence of a stenosis in the LMCA (if a patient is not eligible for CABG) is considered a Class Ilb or lla indication for $\mathrm{PCl}$, respectively. ${ }^{24,25}$ According to these guidelines, when a patient is eligible for CABG, PCI has a class III indication, irrespective of the lesion location. Some retrospective studies evaluating surgical treatment for this disease reported an in-hospital mortality varying from 1.7 to $7.0 \%$ and a 1 -year mortality of $6-14 \% .{ }^{26-30}$ Recently, encouraging results have been reported with elective DES implantation in LMCA with a 1 -year mortality of $0-5 \% .{ }^{11,13,17,31}$ The need for TLR in these registries varied from 0 to $14 \% .^{11,13,17,19,31}$ Indeed, the presence of ostial and mid-shaft lesions in the LMCA was associated with a more favourable outcome and an extremely low restenosis rate. ${ }^{12,32}$

Recently some concerns have been raised about the long-term safety of DES implantation. ${ }^{1-10}$ A multicentre registry analysing $>3000$ patients electively treated with DES (in $67 \%$ for an off-label indication) reported a ST incidence, at 18 months, of $1.9 \%$ (which included definite and possible ST). ${ }^{1}$ Half of the events occurred within 30 days. Similarly, another registry reported that most (60\%) ST occurs within 30 days. $^{3}$ In this study, which included patients with acute coronary syndromes, a $2.9 \%$ cumulative incidence of definite ST was reported in 8146 patients at 3 years.
The presence of an acute coronary syndrome was an independent predictor of ST.

No study has thus far addressed the issue of ST following DES implantation in the subset of unprotected LMCA lesions. Our study represents the largest $(n=731)$ series of patients with unprotected LMCA lesions electively treated with DES. According to clinical and lesion characteristics, our study population was at moderately low surgical risk (Euroscore $\geq 6$ in almost $36 \%$ of the patients), but at intermediate risk for angioplasty (distal left main in $76 \%$ of the patients). The occurrence of in-hospital MACE, which included non-Q-wave MI (defined as an elevation of serum CK MB isoenzyme that was three times ULN), was in accordance with previous reports. Only four (0.5\%) patients had a definite ST and all of them were on DAT at the time of the event. This finding may point out the importance of evaluating individual responsiveness to antiplatelet therapy. ${ }^{33}$ Interestingly one patient, who developed intra-procedural ST and in whom we measured platelet inhibition, was found to be a non-responder to clopidogrel. In three (75\%) patients, definite ST occurred within 30 days and only in one at 3.9 months. All the four patients who had definite ST survived from the event after having been successfully treated: three with repeat $\mathrm{PCl}$ and one with $\mathrm{CABG}$. Three of the patients are still alive at the time of this report and one died because of lung cancer.

Even if we consider definite and probable ST together (which included three deaths within 30 days in the absence of angiographic or pathological confirmation of ST) the low incidence of $0.95 \%$ is still quite reassuring. Again, all patients had the event while on 
(A)

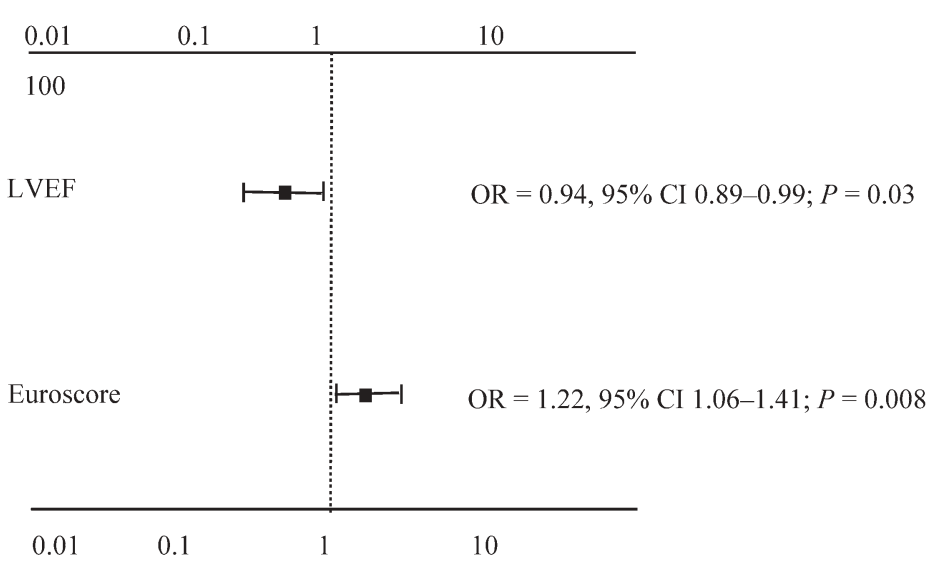

(B)

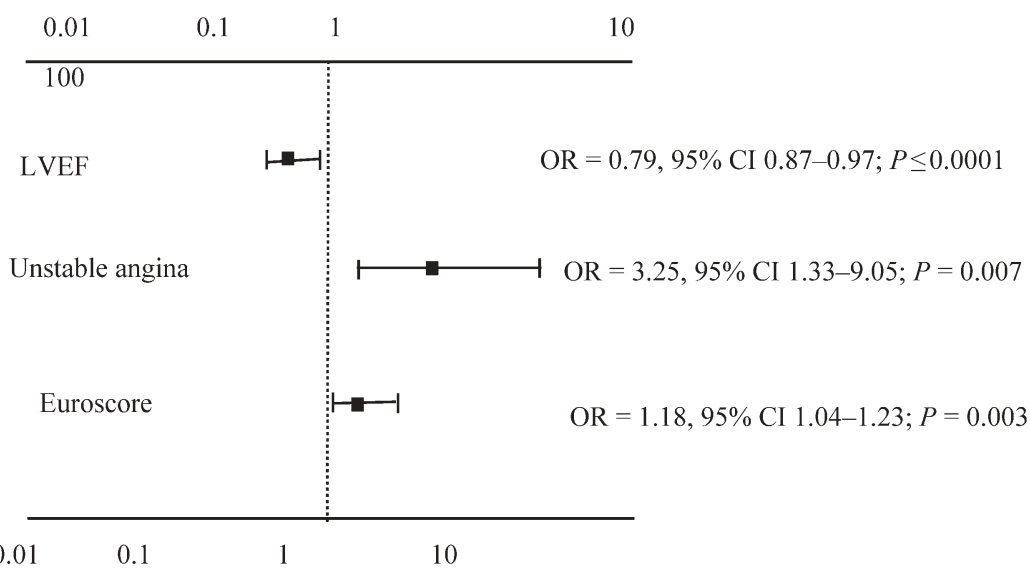

Figure I Predictors at conditional analysis of definite or probable stent thrombosis $(A)$ and cardiac death (B).

DAT. At conditional exact logistic analysis, the occurrence of definite and probable ST was correlated with Euroscore and LVEF. This finding is consistent with predictors identified in general PCl populations. ${ }^{1,3}$ Therefore, no unique ST predictor among LMCA lesions was identified in our analysis.

Regarding the 20 (2.7\%) patients with possible ST (unexplained deaths after 30 days) we need to take into account that many of these patients had high risk characteristics for cardiac death unrelated to ST (Table 6); at conditional exact logistic analysis, cardiac death was correlated to Euroscore and LVEF. Moreover, at least nine of the patients with probable ST would meet the inclusion criteria for MADIT II (multicentre automatic defibrillator implantation trial), which reported an expected overall mortality of $19.8 \%$ and a sudden cardiac death rate of $9.8 \%$ at 2 years in the control group. ${ }^{34,35}$ Eight patients were still on DAT at the time of death and 12 were not (10 suspended DAT according to the hospital protocol and only two prematurely).

Furthermore, the cumulative occurrence of death (cardiac and non-cardiac) at $29.5 \pm 13.7$ months follow-up was 4.2 and $6.2 \%$, respectively. These rates are encouraging if compared with mortality rates following $C A B G$ at a similar clinical follow-up time period.
The low rates of cardiac death in our study could also be justified by the exclusion of patients presenting with a MI. In addition, we cannot exclude that the low rate of cardiac events reported in our study were due to the fact that LM stenting was performed in highly experienced centres.

Additionally, only 11 (1.5\%) patients experienced a Ml during follow-up, nine of which were not in the target vessel. Interestingly, two were due to angiographically proven ST not in the target vessel.

In our registry the long-term efficacy of DES in this subset of lesions is confirmed by a TLR and TVR rate ( 83 re-PCls and 12 CABG) of 10 and $13 \%$, respectively, and a restenosis rate of $14 \%$ even with $76 \%$ of lesions involving the distal LMCA. So far, no randomized data comparing PCl with DES implantation vs. CABG are available. 11,15,16 The 'Synergy between Percutaneous Intervention with TAXUS ${ }^{\circledR}$ and Cardiac Surgery' (SYNTAX) trial was recently conducted and included 710 patients with left main disease randomized to receive either a PES or CABG. Interestingly, the study was not powered to detect any difference between CABG and $\mathrm{PCl}$ with DES in the subset of unprotected LMCA lesions but only in triple-vessel disease. 


\section{Table 6 Characteristics of the patients with possible stent thrombosis}

\begin{tabular}{|c|c|c|c|c|c|c|c|c|c|}
\hline Patient & $\begin{array}{l}\text { Euro } \\
\text { score }\end{array}$ & $\begin{array}{l}\text { Age } \\
\text { (years) }\end{array}$ & $\begin{array}{l}\text { LVEF } \\
\text { (\%) }\end{array}$ & $\begin{array}{l}\text { Unstable } \\
\text { angina }\end{array}$ & $\begin{array}{l}\text { Lesion } \\
\text { location }\end{array}$ & $\begin{array}{l}\text { Stent } \\
\text { type }\end{array}$ & $\begin{array}{l}\text { Stenting } \\
\text { technique }\end{array}$ & $\begin{array}{l}\text { Time of the } \\
\text { event (days) }\end{array}$ & $\begin{array}{l}\text { DAT at the time } \\
\text { of the event }\end{array}$ \\
\hline 1 & 8 & 72 & 26 & No & Distal & Cypher & Cross-over & 1162 & No \\
\hline 2 & 5 & 65 & 55 & No & Distal & Cypher & V & 175 & No \\
\hline 3 & 0 & 48 & 57 & Yes & Distal & Cypher & Cross-over & 790 & No \\
\hline 4 & 3 & 53 & 61 & Yes & Distal & Cypher & Crush & 546 & No \\
\hline 5 & 13 & 82 & 28 & Yes & Distal & Cypher & Crush & 154 & No \\
\hline 6 & 7 & 66 & 35 & Yes & Distal & Cypher & Cross-over & 1390 & Yes \\
\hline 7 & 11 & 71 & 20 & Yes & Distal & Taxus & Crush & 443 & Yes \\
\hline 8 & 4 & 63 & 65 & No & Distal & Taxus & Crush & 955 & No \\
\hline 9 & 5 & 54 & 35 & No & Distal & Cypher & V & 986 & Yes \\
\hline 10 & 4 & 72 & 30 & No & Distal & Cypher & Cross-over & 623 & Yes \\
\hline 11 & 9 & 77 & 30 & Yes & Distal & Taxus & Cross-over & 270 & No \\
\hline 12 & 11 & 80 & 30 & Yes & Distal & Taxus & Culotte & 156 & No \\
\hline 13 & 6 & 56 & 40 & Yes & Distal & Taxus & Cross & 699 & No \\
\hline 14 & 8 & 75 & 45 & Yes & Ostium & Cypher & $N / A$ & 1149 & No \\
\hline 15 & 10 & 72 & 40 & Yes & Distal & Taxus & Culotte & 352 & No \\
\hline 16 & 9 & 80 & 30 & Yes & Distal & Taxus & Cross-over & 243 & No \\
\hline 17 & 4 & 78 & 60 & Yes & Distal & Taxus & Cross-over & 482 & Yes \\
\hline 18 & 11 & 82 & 30 & No & Distal & Taxus & Cross-over & 180 & Yes \\
\hline 19 & 10 & 51 & 25 & Yes & Distal & Cypher & Cross-over & 757 & Yes \\
\hline 20 & 25 & 81 & 50 & Yes & Ostium & Taxus & $N / A$ & 99 & Yes \\
\hline
\end{tabular}

LVEF, left ventricular ejection fraction; DAT, dual antiplatelet therapy; N/A, not applicable.

Table 7 Major adverse cardiac event at hospitalization and at long-term clinical follow-up

\begin{tabular}{|c|c|c|}
\hline & In-hospital, $n=731$ & Follow-up, $n=726$ \\
\hline Cardiac death, $n$ (\%) & $5(0.7)$ & $26(3.6)$ \\
\hline Total death, $n(\%)$ & $5(0.7)$ & $40(5.5)$ \\
\hline MI, $n$ (\%) & $69(9.4)$ & $11(1.5 \%)$ \\
\hline TLR, n (\%) & $2(0.3)$ & $76(10.5)$ \\
\hline TVR, n (\%) & $2(0.3)$ & $95(13.0)$ \\
\hline MACE, $n(\%)$ & 73 (9.9\%) & $138(19.0)$ \\
\hline
\end{tabular}

\section{Study limitations}

This is a retrospective multicentre registry. No 'a priori' sample size has been calculated. Another limitation is the length of clinical follow-up. Moreover we cannot exclude that some of the unexplained deaths that occurred at follow-up could have been a ST because of the absence of an angiographic and/or pathological examination. Different durations of DAT were prescribed among the centres due to different institutional practices.

\section{Conclusions}

In this multicentre registry, the elective use of DES in unprotected LMCA stenosis appears to be safe and effective at $29.5 \pm 13.7$ clinical follow-up. Definite and probable ST occurred in $0.9 \%$ of the patients. Further studies with longer durations of follow-up as well as uniform and prespecified durations of DAT are needed in order to better clarify the issue of safety following DES implantation in unprotected LMCA lesions.

Conflict of interest: the authors do not have any financial associations to disclose that might pose a conflict of interest in connection with the submitted article.

\section{References}

1. Airoldi F, Colombo A, Morici N, Latib A, Cosgrave J, Buellesfeld L, Bonizzoni E, Carlino M, Gerckens U, Godino C, Melzi G, Michev I, Montorfano M, Sangiorgi GM, Qasim A, Chieffo A, Briguori C, Grube E. Incidence and predictors of drug-eluting stent thrombosis during and after discontinuation of thienopyridine treatment. Circulation 2007;116:745-754.

2. Spaulding C, Daemen J, Boersma E, Cutlip DE, Serruys PW. A pooled analysis of data comparing sirolimus-eluting stents with bare-metal stents. N Engl J Med 2007; 356:989-997.

3. Daemen J, Wenaweser P, Tsuchida K, Abrecht L, Vaina S, Morger C, Kukreja N, Juni P, Sianos G, Hellige G, van Domburg RT, Hess OM, Boersma E, Meier B, Windecker S, Serruys PW. Early and late coronary stent thrombosis of sirolimus-eluting and paclitaxel-eluting stents in routine clinical practice: data from a large two-institutional cohort study. Lancet 2007;369:667-678. 
4. Farb A, Boam AB. Stent thrombosis redux - the FDA perspective. N Engl J Med 2007;356:984-987.

5. Kastrati A, Mehilli J, Pache J, Kaiser C, Valgimigli M, Kelbaek H, Menichelli M, Sabate M, Suttorp MJ, Baumgart D, Seyfarth M, Pfisterer ME, Schomig A. Analysis of 14 trials comparing sirolimus-eluting stents with bare-metal stents. N Engl ] Med 2007; 356:1030-1039.

6. Lagerqvist B, James SK, Stenestrand U, Lindback J, Nilsson T, Wallentin L. Longterm outcomes with drug-eluting stents versus bare-metal stents in Sweden. N Engl J Med 2007;356:1009-1019.

7. Maisel WH. Unanswered questions - drug-eluting stents and the risk of late thrombosis. N Engl J Med 2007;356:981-984.

8. Mauri L, Hsieh WH, Massaro JM, Ho KK, D’Agostino R, Cutlip DE. Stent thrombosis in randomized clinical trials of drug-eluting stents. N Engl J Med 2007;356: 1020-1029.

9. Shuchman M. Debating the risks of drug-eluting stents. N Engl J Med 2007;356: 325-328.

10. Stone GW, Moses JW, Ellis SG, Schofer J, Dawkins KD, Morice MC, Colombo A, Schampaert E, Grube E, Kirtane AJ, Cutlip DE, Fahy M, Pocock SJ, Mehran R, Leon MB. Safety and efficacy of sirolimus- and paclitaxel-eluting coronary stents. N Engl J Med 2007;356:998-1008.

11. Chieffo A, Morici N, Maisano F, Bonizzoni E, Cosgrave J, Montorfano M, Airoldi F, Carlino M, Michev I, Melzi G, Sangiorgi G, Alfieri O, Colombo A. Percutaneous treatment with drug-eluting stent implantation versus bypass surgery for unprotected left main stenosis: a single-center experience. Circulation 2006;113: 2542-2547.

12. Chieffo A, Park SJ, Valgimigli M, Kim YH, Daemen J, Sheiban I, Truffa A, Montorfano M, Airoldi F, Sangiorgi G, Carlino M, Michev I, Lee CW, Hong MK, Park SW, Moretti C, Bonizzoni E, Rogacka R, Serruys PW, Colombo A. Favorable long-term outcome after drug-eluting stent implantation in nonbifurcation lesions that involve unprotected left main coronary artery: a multicenter registry. Circulation 2007;116:158-162.

13. Chieffo A, Stankovic G, Bonizzoni E, Tsagalou E, lakovou I, Montorfano M, Airoldi F, Michev I, Sangiorgi MG, Carlino M, Vitrella G, Colombo A. Early and mid-term results of drug-eluting stent implantation in unprotected left main. Circulation 2005;111:791-795.

14. de Lezo JS, Medina A, Pan M, Delgado A, Segura J, Pavlovic D, Melian F, Romero M, Burgos L, Hernandez E, Urena I, Herrador J. Rapamycin-eluting stents for the treatment of unprotected left main coronary disease. Am Heart J 2004;148:481-485

15. Lee MS, Kapoor N, Jamal F, Czer L, Aragon J, Forrester J, Kar S, Dohad S, Kass R, Eigler N, Trento A, Shah PK, Makkar RR. Comparison of coronary artery bypass surgery with percutaneous coronary intervention with drug-eluting stents for unprotected left main coronary artery disease. J Am Coll Cardiol 2006;47:864-870.

16. Palmerini T, Marzocchi A, Marrozzini C, Ortolani P, Saia F, Savini C, Bacchi-Reggiani L, Gianstefani S, Virzi S, Manara F, Kiros Weldeab M, Marinelli G, Di Bartolomeo R, Branzi A. Comparison between coronary angioplasty and coronary artery bypass surgery for the treatment of unprotected left main coronary artery stenosis (the Bologna Registry). Am J Cardiol 2006;98: 54-59.

17. Park SJ, Kim YH, Lee BK, Lee SW, Lee CW, Hong MK, Kim J], Mintz GS, Park SW. Sirolimus-eluting stent implantation for unprotected left main coronary artery stenosis: comparison with bare metal stent implantation. J Am Coll Cardiol 2005; 45:351-356.

18. Price MJ, Cristea E, Sawhney N, Kao JA, Moses JW, Leon MB, Costa RA, Lansky AJ, Teirstein PS. Serial angiographic follow-up of sirolimus-eluting stents for unprotected left main coronary artery revascularization. J Am Coll Cardiol 2006;47:871-877.

19. Valgimigli M, van Mieghem CAG, Ong ATL, Aoki J, Rodriguez Granillo GA, McFadden E, Kappetein AP, de Feijter P, Smits PC, Regar E, van der Giessen WJ, Sianos G, de Jaegere P, Van Domburg RT, Serruys PW. Short- and Long-term Clinical Outcome after Drug-Eluting Stent Implantation for the Percutaneous Treatment of Left Main Coronary Artery Disease. Circulation 2005;111: 1383-1389.

20. Chieffo A, Bonizzoni E, Orlic D, Stankovic G, Rogacka R, Airoldi F, Mikhail GW, Montorfano M, Michev I, Carlino M, Colombo A. Intraprocedural stent thrombosis during implantation of sirolimus-eluting stents. Circulation 2004;109: 2732-2736.

21. Colombo A, Drzewiecki J, Banning A, Grube E, Hauptmann K, Silber S, Dudek D, Fort S, Schiele F, Zmudka K, Guagliumi G, Russell ME. Randomized study to assess the effectiveness of slow- and moderate-release polymer-based paclitaxel-eluting stents for coronary artery lesions. Circulation 2003;108:788-794.

22. Nashef SA, Roques F, Michel P, Gauducheau E, Lemeshow S, Salamon R. European system for cardiac operative risk evaluation (EuroSCORE). Eur J Cardiothorac Surg 1999;16:9-13.

23. Mehta CR, Patel NR. Exact logistic regression: theory and examples. Stat Med 1995;14:2143-2160.

24. Silber S, Albertsson P, Aviles FF, Camici PG, Colombo A, Hamm C, Jorgensen E, Marco J, Nordrehaug JE, Ruzyllo W, Urban P, Stone GW, Wijns W. Guidelines for percutaneous coronary interventions. The Task Force for Percutaneous Coronary Interventions of the European Society of Cardiology. Eur Heart J 2005;26: 804-847.

25. Smith SC Jr, Feldman TE, Hirshfeld JW Jr, Jacobs AK, Kern MJ, King SB, Morrison DA, O'Neill WW, Schaff HV, Whitlow PL, Williams DO, Antman EM, Adams CD, Anderson JL, Faxon DP, Fuster V, Halperin JL, Hiratzka LF, Hunt SA, Nishimura R, Ornato JP, Page RL, Riegel B. ACC/AHA/ SCAI 2005 guideline update for percutaneous coronary intervention-summary article: a report of the American College of Cardiology/American Heart Association Task Force on practice guidelines (ACC/AHA/SCAI Writing Committee to Update the 2001 guidelines for percutaneous coronary intervention). Circulation 2006;113:156-175.

26. Beauford RB, Saunders CR, Lunceford TA, Niemeier LA, Shah S, Karanam R, Prendergast T, Burns P, Sardari F, Goldstein DJ. Multivessel off-pump revascularization in patients with significant left main coronary artery stenosis: early and midterm outcome analysis. J Card Surg 2005;20:112-118.

27. d'Allonnes FR, Corbineau H, Le Breton H, Leclercq C, Leguerrier A, Daubert C. Isolated left main coronary artery stenosis: long term follow up in 106 patients after surgery. Heart 2002;87:544-548.

28. Hannan EL, Wu C, Smith CR, Higgins RS, Carlson RE, Culliford AT, Gold JP, Jones RH. Off-pump versus on-pump coronary artery bypass graft surgery: differences in short-term outcomes and in long-term mortality and need for subsequent revascularization. Circulation 2007;116:1145-1152.

29. Holm F, Lubanda JC, Semrad M, Rohac J, Vondracek V, Miler I, Vanek I, Golan L, Aschermann M. [Main clinical and surgical determinants of in-hospital mortality after surgical revascularization of left main coronary artery stenosis: 2 year retrospective study (1998-1999)]. J Mal Vasc 2004;29:89-93.

30. Lu JC, Grayson AD, Pullan DM. On-pump versus off-pump surgical revascularization for left main stem stenosis: risk adjusted outcomes. Ann Thorac Surg 2005;80: $136-142$.

31. Sheiban I, Meliga E, Moretti c, Fumagalli A, Omedè P, Sciuto F, Grossomarra W, Trevi G. Sirolimus-eluting stents vs. bare metal stents for the treatment of unprotected left main coronary artery stenosis. Eurointervention 2006;2:356-362.

32. Colombo A, Chieffo A. Drug-eluting stent update 2007: part III: technique and unapproved/unsettled indications (left main, bifurcations, chronic total occlusions, small vessels and long lesions, saphenous vein grafts, acute myocardial infarctions, and multivessel disease). Circulation 2007;116:1424-1432.

33. Buonamici P, Marcucci R, Migliorini A, Gensini GF, Santini A, Paniccia R, Moschi G, Gori AM, Abbate R, Antoniucci D. Impact of platelet reactivity after clopidogrel administration on drug-eluting stent thrombosis. J Am Coll Cardiol 2007;49: 2312-2317.

34. Moss AJ, Zareba W, Hall WJ, Klein H, Wilber DJ, Cannom DS, Daubert JP, Higgins SL, Brown MW, Andrews ML. Prophylactic implantation of a defibrillator in patients with myocardial infarction and reduced ejection fraction. N Engl J Med 2002;346:877-883.

35. Greenberg H, Case RB, Moss AJ, Brown MW, Carroll ER, Andrews ML. Analysis of mortality events in the multicenter automatic defibrillator implantation trial (MADIT-II). J Am Coll Cardiol 2004;43:1459-1465.

The above article uses a new reference style being piloted by the $\mathrm{EHJ}$ that shall soon be used for all articles. 